\title{
RUTH BADER GINSBURG'S JURISPRUDENCE OF OPPORTUNITY AND EQUALITY
}

\author{
Deborah Jones Merritt* E David M. Lieberman**
}

Two timeless women embody the ideals of our nation. In New York Harbor, the Statue of Liberty proclaims: "Give me your tired, your poor, / Your huddled masses yearning to breathe free ...."1 In Washington, D.C., the statue Contemplation of Justice sits solemnly before the main entrance to the Supreme Court of the United States. ${ }^{2}$ Above her head, on the building's architrave, appear the words "Equal Justice Under Law." These two promises, of opportunity and equality, have marked our nation's vision since its founding.

The pledge of "equal justice under law" is a profound one, positing a judicial system free of corruption and favoritism as well as one that disdains distinctions of class and caste. The true achievement of our country has been not merely the original expression of this idea, but our willingness to expand our commitment, gradually, to include propertyless white men, former male slaves, other men of color, women of all races, people with disabilities, gay and lesbian citizens, and others within the circle originally reserved for the propertied white men who founded our nation. We began with a transcendent principle, but we have also had the humility to recognize our failings and to revise our behavior to draw closer to our ideal.

Ruth Bader Ginsburg's work embodies that quest, as well as the delicate balance between honoring the timelessness of our Constitution and recognizing the depth of its enduring principles in new centuries and under new circumstances. "[T] he equal dignity of individuals is part of the constitutional legacy," Justice Ginsburg wrote recently, "shaped and

* Director, the John Glenn Institute for Public Service and Public Policy; John Deaver Drinko/Baker \& Hostetler Chair in Law, both at The Ohio State University.

** B.A., The Ohio State University, 2003; J.D. Candidate, Stanford University, 2006; Research Intern, the John Glenn Institute, 2003.

I. The words attributed to the Statue are those of another woman, Emma Lazarus, who penned them in I883. Lazarus wrote her famous sonnet, "The New Colossus," for an auction held to raise funds to construct the Statue's pedestal. Nat'l Park Serv., The "New Colossus," at http://www.nps.gov/stli/plaque/index.html (last visited Oct. 22, 2003) (on file with the Columbia Law Review).

2. James Earle Fraser sculpted both the Contemplation of Justice and her matching male figure, the Guardian or Authority of Law. The Court Building, at http://www. supremecourtus.gov/about/courtbuilding.pdf (last visited Oct. 22, 2003) (on file with the Columbia Law Review). 
bequeathed to us by the framers, in a most vital sense." ${ }^{3}$ But the legacy is not fixed; it embraces a "still evolving American ideal."4

In these remarks, we highlight some of the ways in which Justice Ginsburg has helped shape our evolving notions of opportunity and equality during her first decade on the Supreme Court of the United States. We focus primarily on her contributions to gender equality, a field she created as a professor and advocate, but note too the broader impact of her work.

\section{WOMEN IN THE WORKPLACE}

Justice Ginsburg's very first opinion as a Supreme Court Justice, a brief concurrence in Harris $v$. Forklift Systems, Inc. ${ }^{5}$ demonstrates the utility of her commitment to gender equality. The Court in Harris unanimously allowed workers to pursue a Title VI1 claim for sexual harassment without proving serious psychological harm. But while the other eight members of the Court struggled to locate the boundary at which harassment becomes actionable, Ginsburg found that task easy. Understanding that women, like men, are in the workplace to get a job done, Justice Ginsburg observed that Title VI1 inquires only "whether members of one sex are exposed to disadvantageous terms or conditions of employment to which members of the other sex are not exposed." 6 If a "reasonable person subjected to th [at] discriminatory conduct would find ... that the harassment so altered working conditions as to "make it more difficult to do the job," and the plaintiff suffers the increase in job difficulty, then Title VI1 supports a claim. ${ }^{7}$

The majority, in contrast, focused on whether the working "environment would reasonably be perceived, and is perceived, as hostile or abusive." 8 This standard, the Court conceded, was not "mathematically precise." 9 Indeed, it has led to extensive litigation and conflicting results in the lower courts. ${ }^{10}$ By focusing on the female worker's feelings and her

3. Ruth Bader Ginsburg, Foreword to Supreme Court Decisions and Women's Rights, at xi, xii (Clare Cushman ed., 2001). In this foreword, Justice Ginsburg draws upon the inspiring words carved above the Court's entrance. ld. at xi.

4. Id. at xi. The original Constitution and Bill of Rights, as Ginsburg herself has noted, contained no reference to equality. 1d.; see also Deborah Jones Merritt, What's Missing from the Bill of Rights?, 1991 U. 1ll. L. Rev. 765, 765.

5. 510 U.S. 17, 25 (1993) (Ginsburg, J., concurring).

6. Id.

7. Id. (quoting Davis v. Monsanto Chemical Co., 858 F.2d 345, 349 (6th Cir. 1988)); see also Deborah Jones Merritt, Hearing the Voices of Individual Women and Men: Justice Ruth Bader Ginsburg, 20 U. Haw. L. Rev. 635, 638 (1998) [hereinafter Merritt, Voices], for further discussion of the place of Harris in Ginsburg's jurisprudence.

8. 510 U.S. at 22 (citation omitted).

9. Id.

10. In particular, lower courts and commentators have divided over whether hostility and offensiveness sbould be judged from the perspective of a "reasonable person" or a "reasonable woman." Compare, e.g., Brooks v. City of San Mateo, 229 F.3d 917, 926 (9th Cir. 2000) (reasonable woman), and Hurley v. Atlantic City Police Dep't, 174 F.3d 95, 
perception of whether the workplace was "hostile or abusive," the majority unduly complicated its analysis and unwittingly reinforced impressions that women behave emotionally in the workplace. Ginsburg's approach is elegantly simple; her equality principle confers doctrinal clarity. Title VIl treats men and women as equal players in the workforce. If women face different treatment than men, and the distinctive treatment would make it more difficult for a reasonable person to get the job done, then Title VII prohibits the conduct. That is equal opportunity and equal justice.

\section{I. Gender And the Constitution}

Two terms later, in United States $v$. Virginia (VMI), " Justice Ginsburg applied her lucid perspective to a sharply disputed constitutional claim. The United States challenged Virginia's practice of admitting only men to its prestigious military college, the Virginia Military Institute. Writing for six Justices, Ginsburg held this policy unconstitutional under the Equal Protection Clause. ${ }^{12}$ In reaching this result, Ginsburg adroitly cut away potentially confounding issues about women's participation in the military or the advantages of single-sex education. Despite its name and military methods of instruction, only about fifteen percent of VMI's graduates entered career military service. ${ }^{13}$ And the history of higher education in Virginia demonstrated that the state had not established VMI in a genuine effort to offer a diverse array of educational opportunities, both single-sex and coeducational, to its students. ${ }^{14}$ Instead, as Justice Ginsburg concluded, $V M I$ presented a challenge to a state that had "reserv[ed] exclusively to men" an "incomparable . . college" and "the unique educational opportunities [it] affords." 15 The Equal Protection

115-16 (3d Cir. 1999) (same), with, e.g., O'Rourke v. City of Providence, 235 F.3d 713, 728 (1st Cir. 2001) (reasonable person), and Conner v. Schrader-Bridgeport lnt'l, Inc., 227 F.3d 179, 192 (4th Cir. 2000) (same).

11. 518 U.S. 515 (1996).

12. 1d. at 519. Chief Justice Rehnquist concurred in the judgment, id. at 558; Justice Scalia dissented, id. at 566; and Justice Thomas, whose son attended VMI, took no part in the decision, id. at 518.

13. 1d. at 550 .

14. Id. at $535-40$.

15. Id. at 519. Later, reflecting on $V M I$ in her Wilson Lecture at Wellesley College, Ginsburg observed:

[T] he VMl case was not really about the military. Nor did the Court question the value of single-sex schools. Instead, VMl was about a State that invested heavily in a college designed to produce business and civic leaders, that for generations succeeded admirably in the endeavor, and that strictly limited this unparalleled opportunity to men.

Ruth Bader Ginsburg, The Supreme Court: A Place for Women, Lecture at Wellesley College (Nov. 13, 1998), available at http://www.wellesley.edu/PublicAffairs/Releases/ 1998/111098.html (on file with the Columbia Law Review). 
Clause forbade these "artificial constraints on an individual's opportunity." 16

Justice Ginsburg's discussion of equality in the VMI decision drew heavily on notions of opportunity. The Equal Protection Clause, she posited, guarantees "full citizenship stature" to women and men, a stature that assures "equal opportunity to aspire, achieve, participate in and contribute to society based on their individual talents and capacities." 17 "State actors controlling gates to opportunity," she reminded the Court, "may not exclude qualified individuals based on "fixed notions concerning the roles and abilities of males and females." 18 Ginsburg's references to opportunity are both ageless in their evocation of a fundamental American ideal and novel-at least to some supporters of VMl-in applying that principle to a previously all-male school using military methods of instruction.

Ginsburg herself recognized in VMI the inherent progressivism of our commitment to equality. "A prime part of the history of our Constitution," she wrote, "is the story of the extension of constitutional rights and protections to people once ignored or excluded." 19 As "our comprehension of 'We the People' [has] expanded," institutions like VMl have had to match that evolution. ${ }^{20}$ We are a nation on the move, not just in our wagon trains and automobiles, but in our commitment to equality.

The $V M I$ opinion, finally, expresses Ginsburg's dedication to equality as a means of maximizing both self actualization and social goods. Most women, like most men, have no taste for VMl's adversative methods of instruction. ${ }^{21}$ But evidence in the lower court demonstrated that some women wanted to attend VMI, met all of the school's admissions standards, and were capable of following its rigorous program. ${ }^{22}$ It was "on behalf of these women," no matter how few, that the United States sued; Virginia could no longer exclude those women from a unique "state-supplied educational opportunity for which they are fit." 23 Admitting qualified women, moreover, would advance Virginia's own interest in training "citizen-soldiers." By categorically excluding women, "in total disregard

16. 518 U.S. at 533.

17. Id. at 532.

18. Id. at 541 (quoting Miss. Univ. for Women v. Hogan, 458 U.S. 718, 725 (1982)); see also id. at 550 ('[G]eneralizations about 'the way women are,' estimates of what is appropriate for most women, no longer justify denying opportunity to women whose talent and capacity place them outside the average description.").

19. Id. at 557 (citing Richard B. Morris, The Forging of the Union, 1781-1789, at 193 (1987)).

20. Id. Earlier in its history, Ginsburg observed, VMI "successfully managed another notable change," admitting African American cadets to its student body. Id. at 546 n.16.

21. Id. at 542 .

22. Id. at 550 .

23. Id. at 550-51. 
of their individual merit," from the ranks of VMI, Virginia was reducing its own corps of leaders. ${ }^{24}$

Justice Ginsburg's subsequent dissent in Miller v. Albright ${ }^{25}$ strikes the same chords of equality, opportunity, and individual liberty. In Miller, a fractured Court confronted the constitutionality of an Immigration and Nationality Act provision distinguishing between illegitimate children born outside the United States to citizen mothers and citizen fathers. ${ }^{26}$ Justice Ginsburg, writing for herself and two other Justices, considered the provision a clear violation of equal protection. Using gender stereotypes to control the literal "gates to opportunity" conferred by citizenship transgressed the Court's equal protection rulings in $V M I$ and other precedents. ${ }^{27}$ The government could achieve its stated purpose, limiting citizenship to foreign-born children with "close ties to the United States," through classifications or inquiries unburdened by gender stereotypes. ${ }^{28}$ Doing so would be fair to the individuals affected and generous to the society that would reap their talents. Quoting Burnita Shelton Matthews, the first female U.S. district judge, Ginsburg concluded in Albright that "[w] hether there are a lot of people who suffer or whether there are a few who suffer" from gender stereotypes, "it seems to us that the principle of equal application of the law to men and women ought to receive recognition." 29

\section{EQual, Not FAVORED}

As one might expect from such a staunch defender of individual opportunity, Justice Ginsburg's commitment to gender equality does not mean that women always win. By assuming economic and social opportunity equal to men, women also take on equal responsibilities of citizenship. Justice Ginsburg's concurring opinion in Bennis v. Michigan ${ }^{30}$ offers an especially provocative illustration of this principle.

24. Id. at $545-46$.

25. 523 U.S. 420, 460 (1998) (Ginsburg, J., dissenting).

26. Id. at 424 .

27. Id. at 469 (Ginsburg, J., dissenting) (quoting VMI, 5 I8 U.S. at 541). Notably, the statute challenged in Miller disadvantaged citizen fathers rather than citizen mothers. Id. at 461 (Ginsburg, J., dissenting). In disapproving the statute, Ginsburg followed a pattern established early in her career: challenging gender stereotypes that burden men as well as those that burden women. All gender stereotypes, she frequently notes, harm the interests of both sexes. See generally Merritt, Voices, supra note 7, at 635-36, 643-45 ("Shattering sex-based stereotypes, Ginsburg has always maintained, benefits men as well as women.").

28. 523 U.S. at 470 (Ginsburg, J., dissenting).

29. Id. at 47I (Ginsburg, J., dissenting) (quoting Relating to Naturalization and Citizenship Status of Children Whose Mothers Are Citizens of the United States, and Relating to the Removal of Certain Inequities in Matters of Nationality: Hearings on H.R. 3673 and H.R. 77 Before the House Comm. on Immigration and Naturalization, 73d Cong. 36 ( I933) (statement of Burnita Shelton Matthews, Attorney, National Woman's Party) (alteration in original)).

30. 516 U.S. 442, 457 (1996) (Ginsburg, J., concurring). 
In Bennis, a bare majority of the Court sustained the state-ordered forfeiture of a couple's jointly owned automobile after the husband was caught cavorting with a prostitute in the car's front seat. ${ }^{31}$ Academic commentators and media pundits chided Justice Ginsburg for voting to uphold forfeiture of the wife's half-interest. ${ }^{32}$ How could the feminist Ginsburg make a woman pay for her husband's sins?

Notably, all four female jurists who reviewed the Bennis case-two on the Michigan Supreme Court and two on the United States Supreme Court-denied Tina Bennis's claim. These women, including Ginsburg, viewed Tina Bennis as an economic actor fully equal to her husband and other men. All property owners who voluntarily entrust their property to others risk forfeiture if the other uses the property for illegal activities. From a constitutional perspective, wives are no different from husbands, brothers, fathers, or neighbors in this respect. ${ }^{33}$ The dissenting Justices and other critics who bemoaned the fate of Tina Bennis implicitly placed her behind the lace curtains of a Victorian drawing room, wringing her hands and powerless either to control her husband's actions or protect her economic interests. None of us fully controls the actions of our family members, but we can refuse to lend them our cars-or insist that they pay us back when they wreck them. Or, if we choose, we can share and share alike in both the joys and losses of ownership. That was Tina Bennis's choice; Justice Ginsburg and her sisters on the bench simply honored it. ${ }^{34}$

Justice Ginsburg similarly recognized women as individuals accountable for their own welfare in Gebser v. Lago Vista Independent School District. ${ }^{35}$ The Gebser majority shielded a school district from Title 1X damages sought by a high-school student sexually harassed by her teacher because no official with "authority to address the alleged discrimination and to institute corrective measures" had "actual knowledge of discrimination ... and fail[ed] adequately to respond." 36 Ginsburg joined Justice Stevens's dissent, endorsing school district liability without actual knowledge of the teacher's wrongdoing. Justice Ginsburg, however, wrote separately to suggest that she would also recognize an "affirmative defense to a Title IX charge of sexual harassment" if the school district had established "an effective policy for reporting and redressing such miscon-

31. Id. at 443.

32. See, e.g., David G. Savage, Innocence Punished: Justice Ginsburg Keys Surprise Ruling in Double Jeopardy Case, 82 A.B.A. J., May 1996, at 47, 48; Stuart Taylor, Jr., A Car 1s Not a Pirate Ship, Am. Law., Apr. 1996, at 39, 39-40.

33. Many states choose to protect "innocent" owners, those who do not know of the illegal activity, from forfeiture of their interest. The question in Bennis was whether the Constitution required Michigan to adopt that policy perspective.

34. For further discussion of the Bennis decision, see Deborah Jones Merritt, Forfeiture and Real Feminism, Legal Times, July 29, 1996, at S35.

35. 524 U.S. 274 (1998).

36. Id. at 290. 
duct." 37 If a school district showed that its "internal remedies were adequately publicized and likely would have provided redress without exposing the complainant to undue risk, effort, or expense," and the aggrieved student "unreasonably failed to avail herself of the school district's preventive and remedial measures," then the student would not be able to recover Title IX damages from the school district. ${ }^{38}$

Justice Ginsburg thus recognized the right of young women to attend school free of sexually predatory behavior by teachers, but also acknowledged that the female students could act to protect their own interests if given appropriate channels. Women, in Ginsburg's view, are not victims; they are full citizens who, when necessary, act as complainants.

\section{BEYOND GENDER}

Justice Ginsburg has extended her commitment to opportunity and equality far beyond gender discrimination. She frequently points to the racial discrimination that still mars our society, eloquently urging thoughtful responses to that bias. In Adarand Constructors $v$. Pena, she observed:

Job applicants with identical resumés, qualifications, and interview styles still experience different receptions, depending on their race. White and African-American consumers still encounter different deals. People of color looking for housing still face discriminatory treatment by landlords, real estate agents, and mortgage lenders. Minority entrepreneurs sometimes fail to gain contracts though they are the low bidders, and they are sometimes refused work even after winning contracts. ${ }^{39}$

More recently, in last Term's Gratz $v$. Bollinger, she stressed:

Unemployment, poverty, and access to health care vary disproportionately by race. Neighborhoods and schools remain racially divided. African-American and Hispanic children are all too often educated in poverty-stricken and underperforming institutions. Adult African-Americans and Hispanics generally earn less than whites with equivalent levels of education. Equally credentialed job applicants receive different receptions depending on their race. Irrational prejudice is still encountered in real estate markets and consumer transactions. ${ }^{40}$

In sum, Ginsburg repeatedly has reminded us: "Bias both conscious and unconscious, reflecting traditional and unexamined habits of thought, keeps up barriers that must come down if equal opportunity and nondiscrimination are ever genuinely to become this country's law and

37. Id. at 307 (Ginsburg, J., dissenting).

38. Id. Justices Souter and Breyer joined Justice Ginsburg's dissent. Id. at 306 (Ginsburg, J., joined by Souter \& Breyer, JJ., dissenting).

39. 515 U.S. 200, 273-74 (1995) (Ginsburg, J., dissenting) (footnotes omitted).

40. 123 S. Ct. 2411, 2443-44 (2003) (Ginsburg, J., dissenting) (footnotes omitted). 
practice." ${ }^{1}$ Cognizant of those barriers, Justice Ginsburg has supported the constitutionality of carefully tailored forms of affirmative action in government contracts, ${ }^{42}$ higher education, ${ }^{43}$ and other contexts. ${ }^{44}$

Justice Ginsburg likewise has sustained equality-of-opportunity claims pressed by disabled citizens. In Olmstead v. Zimring, she held that "unjustified institutional isolation of persons with disabilities is a form of discrimination" violating the Americans with Disabilities Act. ${ }^{45}$ She elaborated a two-fold concept of discrimination, noting that unneeded institutionalization both "perpetuates unwarranted assumptions that persons so isolated are incapable or unworthy of participating in community life," and "severely diminishes the everyday life activities of [these] individuals, including family relations, social contacts, work options, economic independence, educational advancement, and cultural enrichment." 46 Discrimination, in other words, consists of both constraints on an individual's actions and an assault on the individual's dignity. These concepts draw heavily from Ginsburg's jurisprudence of gender and race equality. ${ }^{47}$

\section{The Ginsburg Legacy}

In her ten years on the Supreme Court, Justice Ginsburg has authored several chapters in our ongoing national "story of the extension of constitutional rights and protections to people once ignored or excluded." 48 Those chapters have advanced our "story" in at least three ways. First, Justice Ginsburg has had an enormous impact on the lives of individual women and men. Due to both her jurisprudence and her previous roles as scholar and advocate, women are more welcome in the workplace; they are fulfilling their ambitions and serving society by working as pilots, bricklayers, engineers, university presidents, and governors. Both women and men are free to balance family and work in new ways.

41. Adarand, 515 U.S. at 274 (Ginsburg, J., dissenting); see also Gratz, 123 S. C. at 2444 (Ginsburg, J., dissenting) (quoting Adarand).

42. Adarand, 515 U.S. at 274 (Ginsburg, J., dissenting).

43. Gratz, 123 S. C.t. at 2442-46 (Ginsburg, J., dissenting); Grutter v. Bollinger, $123 \mathrm{~S}$. Ct. 2325, 2347-48 (2003) (Ginsburg, J., concurring).

44. See Ruth Bader Ginsburg \& Deborah Jones Merritt, Affirmative Action: An International Human Rights Dialogue, 54 Rec. Ass'n B. City N.Y. 278 (1999). Justice Ginsburg's writings further reflect an understanding of the "capacity for evolution in the Supreme Court's treatment of affirmative action." Kenneth L. Karst, The Revival of Forward-Looking Affirmative Action, 104 Colum. L. Rev. 60, 69 (2004).

45. 527 U.S. 581, 600 (1999). For a discussion of the impact Olmstead has had on the disability rights movement, see Samuel R. Bagenstos, Justice Ginsburg and the Judicial Role in Expanding "We the People": The Disability Rights Cases, 104 Colum. L. Rev. 49 (2004).

46. 527 U.S. at 600-01. Four Justices joined this portion of Ginsburg's opinion, making it an opinion for the Court.

47. Id. at 600 (citing sex and race discrimination cases).

48. United States v. Virginia, 518 U.S. 515, 557 (1996); see also supra notes 19-20 and accompanying text. 
And few vestiges remain of the statutory disadvantages women suffered for most of our nation's history. ${ }^{49}$

One telling testament to this shift appears in a recent opinion by Chief Justice Rehnquist. During the 1970s, when Ginsburg argued before the Court, the current Chief Justice did not readily support gender bias claims. Last Term, however, Rehnquist authored an opinion upholding provisions of the Family and Medical Leave Act of $1993 .{ }^{50}$ In his majority opinion, Rehnquist decried " $[\mathrm{t}]$ he history of the many state laws limiting women's employment opportunities" that was "chronicled in-and, until relatively recently, was sanctioned by-th [e] Court's own opinions." ${ }^{51}$ In the workplace, he noted, "differential leave policies were not attributable to any differential physical needs of men and women, but rather to the pervasive sex-role stereotype that caring for family members is women's work." 52 These "[s] tereotypes about women's domestic roles," finally, were "reinforced by parallel stereotypes presuming a lack of domestic responsibilities for men." 53 ln sum, the Chief Justice concluded, "[ $t]$ hese mutually reinforcing stereotypes created a self-fulfilling cycle of discrimination that forced women to continue to assume the role of primary family caregiver, and fostered employers' stereotypical views about women's commitment to work and their value as employees." 54 This is a remarkable exposition of gender discrimination by a judge who once dismissed many gender bias claims as "carry[ing] little weight." 55 Justice Ginsburg deserves much credit for this transformation in both our nation's jurisprudence and its attitudes.

Justice Ginsburg's commitment to equality and opportunity has likewise liberated women and men suffering from other forms of bias. In both statutory and constitutional cases, she has pushed to free all individuals from discrimination. Her vision, that we take seriously individual capacity and dignity, continuously finds new ground and affects the lives of individuals.

Second, by working tirelessly to overcome stereotypes in law, Justice Ginsburg has reduced typecast thinking in our everyday lives. Through the constitutional scrutiny for gender discrimination she pioneered as an advocate, as well as her opinions from the bench, Ginsburg has immeasurably advanced the integration of men and women in schools and workplaces. Social psychology research confirms that this type of familiarity, especially when it centers on joint efforts to reach a common goal, breeds

49. But see Carmell $v$. Texas, in which Ginsburg noted the bias in laws limiting the competency of uncorroborated victim testimony in rape trials and dissented from a Court ruling on the ex post facto effect of modifications in one of these laws. 529 U.S. 513, 553-75 (2000) (Ginsburg, J., dissenting).

50. Nev. Dep't of Human Res. v. Hibbs, 123 S. Ct. 1972 (2003).

51. Id. at 1978 .

52. Id. at 1979 .

53. Id. at 1982 .

54. Id.

55. Craig v. Boren, 429 U.S. 190, 220 n.2 (1976) (Rehnquist, J., dissenting). 
new respect. ${ }^{56}$ And by forcing us to focus on individual traits, rather than group stereotypes, Justice Ginsburg has reduced the tenacity of bias. Cognitive research again substantiates the impact of Ginsburg's mental model in inhibiting even deeply held prejudices. ${ }^{57}$

Finally, and perhaps most importantly, Justice Ginsburg's jurisprudence teaches us both the stability and adaptability of our most fundamental principles. As a nation, we have always expressed our fidelity to equality and opportunity, but we have not always lived up to our ideals. Justice Ginsburg shows us that we can cherish our ideals and our past, while continuously pushing toward a brighter future.

Ruth Bader Ginsburg has always eschewed labels of "conservative" or "liberal" for herself and other judges. ${ }^{58}$ But in the best sense of those words, she is both a conservative-someone who maintains our oldest ideals-and a liberal-one who beckons us to new worlds. We join in celebrating her commitment to the timeless ideals of equality and opportunity.

56. See, e.g., Samuel L. Gaertner et al., How Does Cooperation Reduce Intergroup Bias?, in Stereotypes and Prejudice: Essential Readings 435, 446-49 (Charles Stangor ed., 2000) (exploring relationship between "intergroup cooperation and reduced bias").

57. See, e.g., Elizabeth W. Dunn \& Barbara A. SpelIman, Forgetting by Remembering: Stereotype Inhibition Through Rehearsal of Alternative Aspects of Identity, $39 \mathrm{~J}$. Experimental Soc. Psycbol. 420 (2003).

58. See, e.g., 18 Hearings and Reports on Successful and Unsuccessful Nominations of Supreme Court Justices by the Senate Judiciary Committee 1916-1993: Ruth Bader Ginsburg 260 (Roy M. Mersky et al. eds., 1995) (statement of Judge Ruth Bader Ginsburg) ("Let me try to state in a nutsheII how I view the work of judging. My approacb, I believe, is neither 'liberal' nor 'conservative.' Rather, it is rooted in the place of the judiciary-of judges-in our democratic society."); Ruth Bader Ginsburg, Interpretations of the Equal Protection Clause, 9 Harv. J.L. \& Pub. Pol'y 41, 45 (1986) (noting that great judges "have not been born once or reborn Iater liberals or conservatives," but "have been notably skeptical of all party lines"). 